\title{
A Note on Citations of Scott's Works
}

Throughout, I cite passages from the Waverley Novels parenthetically in my text. I use the Dryburgh Edition, 25 vols. (London: Adam and Charles Black, I 892-94). I have checked all passages cited against the versions given in the "Magnum Opus" edition, 48 vols. (Edinburgh: Cadell, I 829-33) without finding any significant variants, except that the Dryburgh edition misspells the name of Montrose's castle. (I have corrected it.) In discussing Scott's prefatory material, I differentiate between Introductions and Notes written for the first editions of the novels, and the material Scott put together retrospectively for the "Magnum Opus" edition.

Abbreviations used in citing other works by Scott are as follows:

Journal The Journal of Sir Walter Scott, ed. W. E. K. Anderson (London: Oxford University Press, 1972).

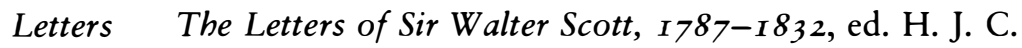
Grierson, I 2 vols. (London: Constable, 1932-37).

MPW The Miscellaneous Prose Works of Sir Walter Scott, Bart., ed. J. G. Lockhart, 28 vols. (Edinburgh: Cadell, I 834-36). 



\section{The Forms of Historical Fiction}


